\title{
The association of body mass index with long-term clinical outcomes after ticagrelor monotherapy following abbreviated dual antiplatelet therapy in patients undergoing percutaneous coronary intervention: a prespecified sub-analysis of the GLOBAL LEADERS Trial
}

\author{
Masafumi Ono ${ }^{1} \cdot$ Ply Chichareon $^{1,2} \cdot$ Mariusz Tomaniak $^{3,4} \cdot$ Hideyuki Kawashima $^{1} \cdot$ Kuniaki Takahashi $^{1}$. \\ Norihiro Kogame ${ }^{1} \cdot$ Rodrigo Modolo $^{1,5} \cdot$ Hironori Hara ${ }^{1} \cdot$ Chao Gao $^{6,7} \cdot$ Rutao Wang $^{6,7}$. Simon Walsh ${ }^{8}$. \\ Harry Suryapranata ${ }^{6} \cdot$ Pedro Canas da Silva $^{9} \cdot$ James Cotton $^{10} \cdot$ René Koning $^{11} \cdot$ lbrahim Akin $^{12}$. \\ Benno J. W. M. Rensing ${ }^{13}$. Scot Garg ${ }^{14}$. Joanna J. Wykrzykowska ${ }^{1}$ Jan J. Piek ${ }^{1}$. Peter Jüni ${ }^{15}$. Christian Hamm ${ }^{16}$. \\ Philippe Gabriel Steg ${ }^{17} \cdot$ Marco Valgimigli $^{18}$. Stephan Windecker ${ }^{18} \cdot$ Robert F. Storey $^{19} \cdot$ Yoshinobu Onuma $^{20}$. \\ Pascal Vranckx ${ }^{21} \cdot$ Patrick W. Serruys ${ }^{20,22}$ (])
}

Received: 3 December 2019 / Accepted: 16 January 2020 / Published online: 31 January 2020

(c) The Author(s) 2020

\begin{abstract}
Background The efficacy of antiplatelet therapies following percutaneous coronary intervention (PCI) may be affected by body mass index (BMI).

Methods and results This is a prespecified subgroup analysis of the GLOBAL LEADERS trial, a prospective, multicenter, open-label, randomized controlled trial in an all-comer population undergoing PCI, comparing the experimental strategy (23-month ticagrelor monotherapy following 1-month dual antiplatelet therapy [DAPT]) with a reference regimen (12-month aspirin monotherapy following 12-month DAPT). A total of 15,968 patients were stratified by baseline BMI with prespecified threshold of $27 \mathrm{~kg} / \mathrm{m}^{2}$. Of those, $6973(43.7 \%)$ patients with a BMI $<27 \mathrm{~kg} / \mathrm{m}^{2}$ had a higher risk of all-cause mortality at 2 years than those with BMI $\geq 27 \mathrm{~kg} / \mathrm{m}^{2}$ (adjusted HR 1.24, 95\% CI 1.02-1.49). At 2 years, the rates of the primary endpoint (all-cause mortality or new Q-wave myocardial infarction) were similar between treatment strategies in either BMI group $\left(p_{\text {interaction }}=0.51\right)$. In acute coronary syndrome, however, the experimental strategy was associated with significant reduction of the primary endpoint compared to the reference strategy in patients with BMI $<27 \mathrm{~kg} / \mathrm{m}^{2}$ (HR $0.69,95 \%$ CI $0.51-0.94$ ), but not in the ones with BMI $\geq 27 \mathrm{~kg} / \mathrm{m}^{2}\left(p_{\text {interaction }}=0.047\right)$. In chronic coronary syndrome, there was no between-group difference in the efficacy and safety of the two antiplatelet strategies.

Conclusions Overall, BMI did not influence the treatment effect seen with ticagrelor monotherapy; however, a beneficial effect of ticagrelor monotherapy was seen in ACS patients with BMI $<27 \mathrm{~kg} / \mathrm{m}^{2}$.

Trial registration The trial has been registered with ClinicalTrials.gov, Number NCT01813435.
\end{abstract}

Masafumi Ono and Ply Chichareon contributed equally to this work.

Electronic supplementary material The online version of this article (https://doi.org/10.1007/s00392-020-01604-1) contains supplementary material, which is available to authorized users.

Extended author information available on the last page of the article 


\section{Graphic abstract}

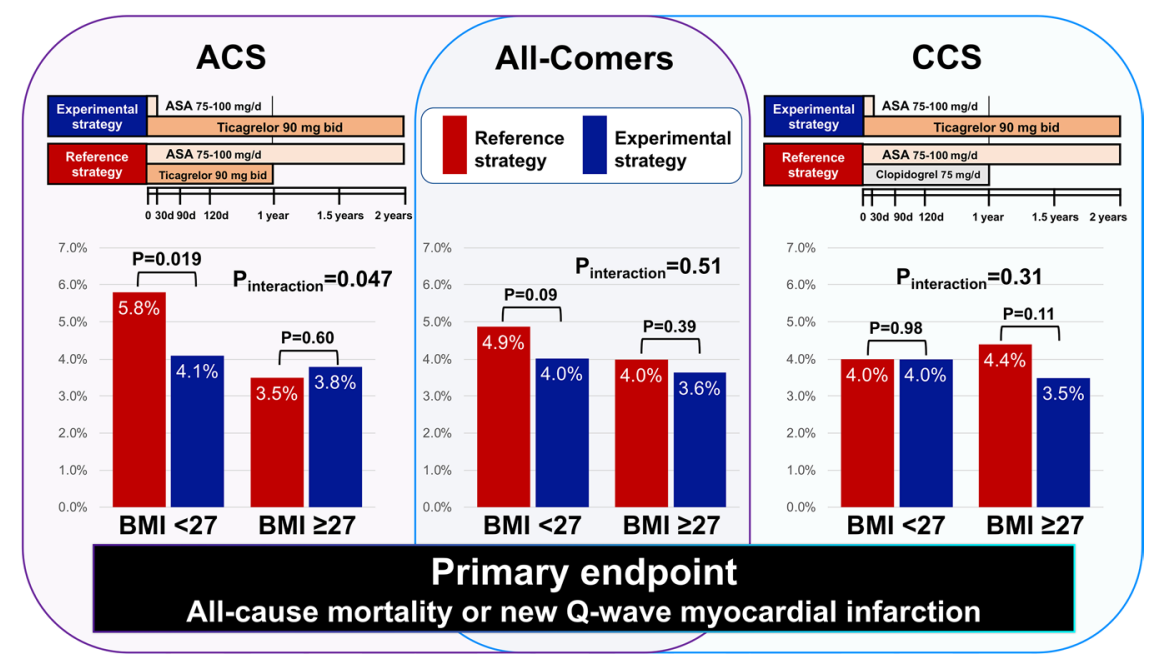

Keywords Body mass index - Percutaneous coronary intervention - Drug-eluting stent $\cdot$ Dual antiplatelet therapy · Ticagrelor monotherapy $\cdot$ Acute coronary syndrome

\author{
Abbreviations \\ ACS Acute coronary syndromes \\ BARC Bleeding Academic Research Consortium \\ BMI Body mass index \\ CCS Chronic coronary syndromes \\ DAPT Dual antiplatelet therapy \\ DES Drug-eluting stent \\ MI Myocardial infarction \\ PCI Percutaneous coronary intervention
}

\section{Introduction}

Body mass index (BMI) is simple to calculate and consequently used as an indicator of general adiposity [1]. Although obesity is well recognized as a major risk factor of cardiovascular disease (CVD) [2], numerous studies have demonstrated a paradoxical association between higher BMI and lower risk of adverse events in patients with established CVD, even after adjusting for confounding factors. In this phenomenon, dubbed the "obesity paradox" [3-5], patients with lower or even normal BMI have a higher risk of both ischemic and bleeding events after percutaneous coronary intervention (PCI) compared to those who are overweight [6]. To date, however, no tailored antiplatelet strategy has been recommended for these patients [7].

It is recognized that the efficacy of platelet inhibition due to antiplatelet therapy including novel potent P2Y12 inhibitors could be associated with a patient's BMI [8]. In other words, high or low BMI could lead to an inappropriate balance between anti-ischemic and bleeding risks [9-11]. Therefore, assessment of different antiplatelet strategies after PCI, stratified according to BMI, may provide additional insight into patients with a "high-risk" BMI.

The GLOBAL LEADERS trial compared the experimental antiplatelet regimen with 23-month ticagrelor monotherapy, to the reference regimen of conventional 12-month dual antiplatelet therapy (DAPT) followed by 12-month aspirin in an all-comers PCI population [12]. The superiority of the experimental strategy at 2 years was not demonstrated in the parent trial. However, non-specified secondary analyses suggested the potential efficacy of this novel experimental regimen in some specific patient subgroups [12-15]. To unravel the complex intricacies of the GLOBAL LEADERS trial, the present study aims to investigate the clinical impact of BMI on the novel antiplatelet strategy with ticagrelor monotherapy in patients undergoing PCI.

\section{Methods}

\section{Study design}

This study is a prespecified subgroup analysis of the GLOBAL LEADERS trial [16]. The GLOBAL LEADERS trial [12] is a multi-center, prospective, open-label randomized controlled trial in an all-comer population with no restriction regarding clinical presentation, complexity 
of the lesions or number of stents used (NCT01813435). Details of the study design and protocol have been reported elsewhere [16]. In brief, the trial randomly assigned patients before PCI to either (i) the experimental strategy with 1-month DAPT (aspirin 75-100 mg daily and ticagrelor $90 \mathrm{mg}$ twice daily) followed by 23 -month ticagrelor $90 \mathrm{mg}$ twice daily monotherapy, or (ii) the reference regimen with 12-month DAPT [aspirin 75-100 mg daily and either ticagrelor $90 \mathrm{mg}$ twice daily for acute coronary syndromes (ACS: unstable angina, non ST-elevation myocardial infarction, and ST elevation myocardial infarction) or clopidogrel $75 \mathrm{mg}$ daily for chronic coronary syndromes (CCS)] followed by 12-month aspirin 75-100 mg daily monotherapy, respectively. All target lesions were treated by default with biolimus A9-eluting stents (BioMatrix, Biosensors, Europe). The trial was approved by the institutional review board at each center and followed the ethical principles of the Declaration of Helsinki. All the patients gave written informed consent prior to participation in the trial.

\section{Patients population and study endpoints}

The patient's baseline BMI was calculated as weight in kilograms divided by height in meters squared collected at the time of randomization. Patients were divided into two groups according to a threshold BMI of $27.0 \mathrm{~kg} /$ $\mathrm{m}^{2}$, which was prespecified in the design paper [16] and adopted by reference to previous publications [17, 18], and also corresponds to the median value of BMI in the present population. In each BMI group, clinical, demographic, angiographic, and procedural characteristics were compared between patients who received the experimental and reference antiplatelet regimen.

The primary endpoint of this study was the composite of all-cause mortality and new Q-wave myocardial infarction (MI) up to 2 years. Deaths from any cause were ascertained without the need for adjudication [19, 20]. Q-wave MI was centrally adjudicated by an independent electrocardiogram core lab and defined in accordance with the Minnesota classification (new major Q-QS wave abnormalities) or by the appearance of a new left bundle branch block in conjunction with abnormal biomarkers [21]. The secondary safety endpoint was major bleeding events according to the Bleeding Academic Research Consortium (BARC) criteria type 3 or 5 [22]. Additional endpoints included stroke (ischemic or hemorrhagic), BARC type 2 bleeding, definite stent thrombosis according to Academic Research Consortium (ARC) definition [23], and the composite of all-cause mortality, any stroke, and new Q-wave MI [16]. The composite endpoints were analyzed according to time-to-first event analysis.

\section{Statistical analysis}

Continuous variables are reported as mean \pm standard deviations (SD) or median and interquartile range (IQR), and are compared using Student's $t$ tests or Mann-Whitney $U$ test, respectively. Categorical variables are reported as percentages and numbers and are compared using Chi-square or Fisher's exact test as appropriate.

Association between baseline BMI as a continuous variable and adverse outcomes including the primary and secondary endpoint is depicted using restricted cubic spline function from the adjusted Cox regression model. Kaplan-Meier method is used to estimate the cumulative rates of clinical events and log-rank test is performed to examine the differences between groups. The effect of BMI on the outcomes is assessed in the unadjusted and adjusted Cox proportional hazards model. The clinical outcomes were compared stratified according to both the prespecified threshold of $27 \mathrm{~kg} /$ $\mathrm{m}^{2}$ and the World Health Organization (WHO) classification: underweight (BMI $<18.5 \mathrm{~kg} / \mathrm{m}^{2}$ ), normal weight (BMI $18.5-24.9 \mathrm{~kg} / \mathrm{m}^{2}$ ), overweight (BMI $25.0-29.9 \mathrm{~kg} / \mathrm{m}^{2}$ ), and obesity (BMI $\geq 30 \mathrm{~kg} / \mathrm{m}^{2}$ ). The covariables in the adjusted model are listed in Fig. 2 and Table 2, which were selected based on previous knowledge and literature [24, 25]. Variance inflation factor (VIF) of covariables are calculated to confirm the absence of multicollinearity. We also performed the receiver operating characteristic (ROC) analysis to detect the optimal cutoff value of BMI for predicting the primary endpoint according to the Youden index. The treatment effect of the experimental vs. the reference strategy between subgroups is estimated with an unadjusted Cox regression model.

Because different $\mathrm{P} 2 \mathrm{Y}_{12}$ inhibitors in the reference group were used depending on clinical presentation (ticagrelor for ACS or clopidogrel for CCS), the prespecified stratified analysis according to clinical presentation is performed. In addition, landmark analyses are reported using the prespecified time points of 1 year (at the time of the planned cessation of a P2 $\mathrm{Y}_{12}$ inhibitor in the reference strategy).

Statistical significance was considered if two-sided $p$ value was less than or equal 0.05. All analyses were performed in SPSS Statistics, version 26 (IBM Corp., Armonk, 281 N.Y., USA) and R software version 3.5.1 (R Foundation for Statistical Computing, Vienna, Austria).

\section{Results}

A total of 15,991 patients at 130 hospitals in 18 countries were enrolled in the GLOBAL LEADERS trial between 1st July 2013 and 9th November 2015; of these 23 patients withdrew their consent and their data were deleted from the database. Of the remaining 15,968 patients included in the 


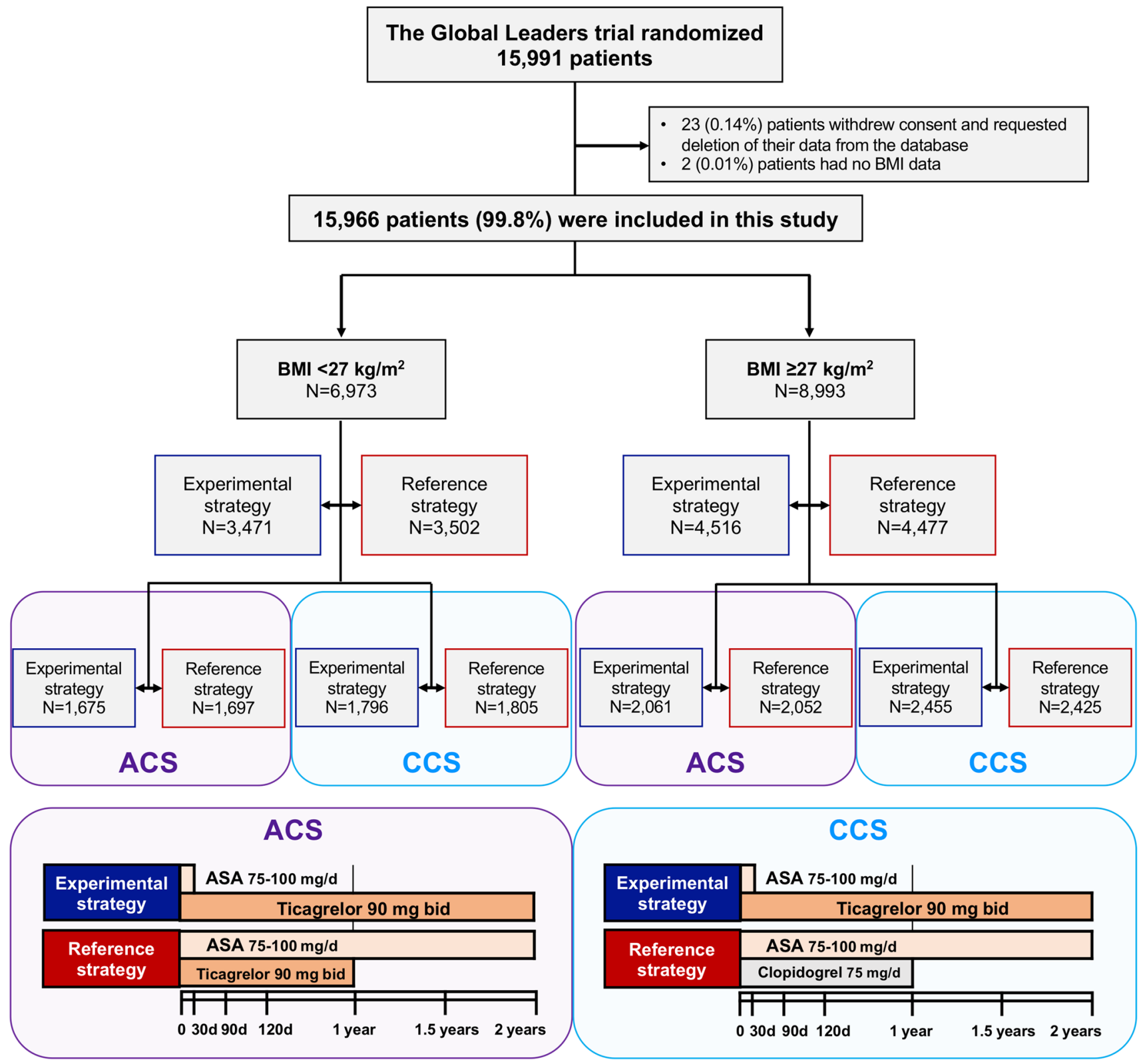

Fig. 1 Flowchart of the present study. Among 15,966 patients included in this analysis, $6973(43.7 \%)$ had $\mathrm{BMI}<27 \mathrm{~kg} / \mathrm{m}^{2}$ and 8993 patients $(56.3 \%)$ had $\mathrm{BMI} \geq 27 \mathrm{~kg} / \mathrm{m}^{2}$. Outcomes were assessed between experimental strategy and reference strategy in all-comers

main study, baseline BMI was available in 15,966 patients (99.99\%) (Fig. 1). The median BMI was 27.68 (interquartile range $25.00-30.69) \mathrm{kg} / \mathrm{m}^{2}$ with $6973(43.7 \%)$ patients with a BMI $<27 \mathrm{~kg} / \mathrm{m}^{2}$ and $8993(56.3 \%)$ patients with a $\mathrm{BMI} \geq 27 \mathrm{~kg} / \mathrm{m}^{2}$. The distribution of patients according to BMI is shown in Fig. 2. population, and furthermore in each clinical presentation (ACS and CCS). BMI body mass index, ACS acute coronary syndrome, $C C S$ chronic coronary syndrome, $A S A$ acetylsalicylic acid

\section{Baseline characteristics}

A comparison of the baseline characteristics between the two BMI groups is shown in Table 1. Compared to those with a BMI $\geq 27 \mathrm{~kg} / \mathrm{m}^{2}$, patients with $\mathrm{BMI}<27 \mathrm{~kg} / \mathrm{m}^{2}$ were older; more likely to present with ACS; had lower prevalence of diabetes, hypertension, hypercholesterolemia, renal impairment, previous MI, and previous PCI; were more likely to be smokers, and had a higher prevalence of peripheral artery disease. Patients with a BMI $<27 \mathrm{~kg} / \mathrm{m}^{2}$ 


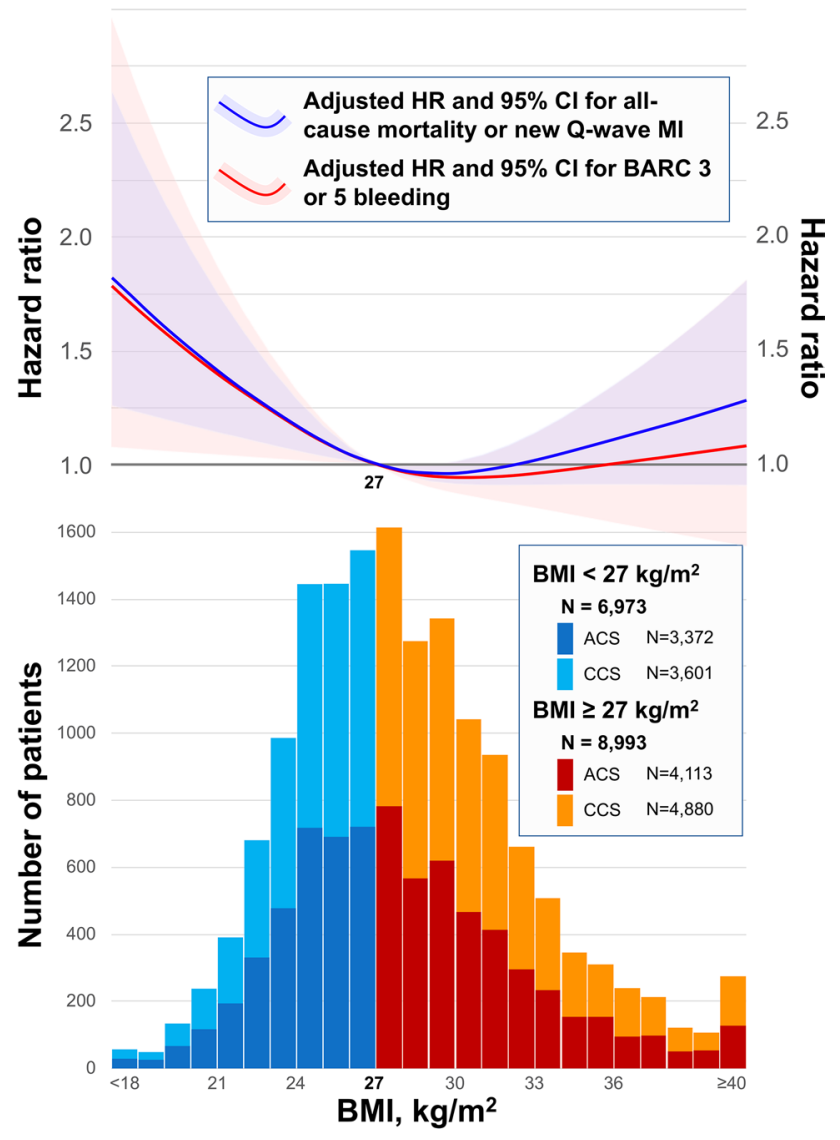

Fig. 2 Histogram of BMI stratified by clinical presentation with adjusted hazard ratio for adverse events according to BMI. Blue and red bar graphs indicate the number of patients with $\mathrm{BMI}<27 \mathrm{~kg} /$ $\mathrm{m}^{2}$ and $\geq 27 \mathrm{~kg} / \mathrm{m}^{2}$ in the setting of ACS, respectively. Similarly, sky blue and orange bar graphs indicate the number of patients with BMI $<27 \mathrm{~kg} / \mathrm{m}^{2}$ and $\geq 27 \mathrm{~kg} / \mathrm{m}^{2}$ in the setting of CCS, respectively. Blue curve with light blue area indicates adjusted hazard ratio with 95\% CI for composite of all-cause mortality and new Q-wave MI at 2-year according to BMI with reference of $27 \mathrm{~kg} / \mathrm{m}^{2}$. Red curve with light red area indicates adjusted hazard ratio with $95 \% \mathrm{CI}$ for BARC type 3 or 5 bleeding according to BMI with reference of $27 \mathrm{~kg} / \mathrm{m}^{2}$. The number of knots for the cubic spline curves were three in each model. Adjusted covariates for all-cause mortality or new Q-wave MI are age (years), sex, clinical presentation (ACS or CCS), diabetes mellitus, hypertension, hypercholesteremia, PVD, COPD, renal impairment, previous MI, previous PCI, and previous CABG. Adjusted covariates for BARC type 3 or 5 bleeding are age (years), sex, clinical presentation (ACS or CCS), diabetes mellitus, previous bleeding, renal impairment, anemia according to WHO classification, and radial access in the index procedure. $B M I$ body mass index, $A C S$ acute coronary syndromes, $C C S$ chronic coronary syndromes, $H R$ hazard ratio, $C I$ confidence interval, $M I$ myocardial infarction, $B A R C$ Bleeding Academic Research Consortium, $P V D$ peripheral vascular disease, $C O P D$ chronic obstructive pulmonary disease, $P C I$ percutaneous coronary intervention, $C A B G$ coronary artery bypass graft, WHO World Health Organization

had higher rates of PCI in the left anterior descending artery compared to those with a BMI $\geq 27 \mathrm{~kg} / \mathrm{m}^{2}$. There were no significant differences in the rates of radial access between the two BMI groups.
Baseline patient characteristics were comparable and well balanced between the experimental and reference arms in each BMI group as shown in online Table 1 .

\section{Comparison of 2-year clinical outcomes between BMI groups}

In a univariate analysis, patients with a BMI $<27 \mathrm{~kg} / \mathrm{m}^{2}$ had at 2 years follow-up a higher rate of the primary endpoint (4.4\% vs. $3.8 \%$, unadjusted HR $1.17,95 \%$ CI $1.00-1.37$, $p=0.044)$ and secondary safety endpoint $(2.4 \%$ vs. $1.9 \%$, unadjusted HR 1.27, 95\% CI 1.02-1.57, $p=0.033$ ) compared with those with $\mathrm{BMI} \geq 27 \mathrm{~kg} / \mathrm{m}^{2}$ (Table 2).

For the multivariable analysis, the VIF values of covariables were all $<2.0$, indicating no evidence for strong multicollinearity. After adjustment for potential confounding factors, the risk of all-cause death at 2 years remained higher in patients with $\mathrm{BMI}<27 \mathrm{~kg} / \mathrm{m}^{2}$ than in patients with $\mathrm{BMI} \geq 27 \mathrm{~kg} / \mathrm{m}^{2}$ (3.4\% vs. $2.7 \%$, unadjusted HR 1.27 , 95\% CI $1.06-1.52, p=0.009$, adjusted HR $1.24,95 \%$ CI $1.02-1.49, p=0.029$ ), but other clinical outcomes including the primary (adjusted HR 1.14, 95\% CI 0.97-1.34, $p=0.12$ ) and secondary endpoint (adjusted HR 1.10, 95\% CI $0.88-1.37, p=0.42$ ) were no longer significantly different between the two BMI groups (Table 2).

The comparison of clinical outcomes according to WHO classification is shown in online Table 2. After adjusting confounding factors, the risk of all-cause mortality at 2 years was significantly lower in overweight patients (HR 0.75, 95\% CI $0.60-0.93, p=0.010$ ) or obese patients (HR $0.74,95 \%$ CI $0.57-0.95, p=0.020$ ) than normal weight patients. The correlation between the risks for the primary or secondary endpoint and BMI as a continuous variable showed reverse J-shape curves, as shown in Fig. 2 and online Table 3. The ROC analysis demonstrated that $25.4 \mathrm{~kg} / \mathrm{m}^{2}$ was the optimal cutoff value of BMI for predicting the primary endpoint.

\section{Impact of BMI on antiplatelet strategy}

The comparison of 2-year outcomes between the experimental and reference arms are shown in Fig. 3. At the 2-year follow-up, there was no statistically significant treatment effect on the primary endpoint of all-cause mortality or new Q-wave MI between the experimental and reference arm in patients with a BMI $<27 \mathrm{~kg} / \mathrm{m}^{2}(4.9 \%$ vs. $4.0 \%$, HR 0.82 , $95 \%$ CI $0.66-1.03, p=0.09$ ), or $\mathrm{BMI} \geq 27 \mathrm{~kg} / \mathrm{m}^{2}$ (4.0\% vs. $3.6 \%, \mathrm{HR} 0.91,95 \%$ CI0.74-1.13, $\left.p=0.39, p_{\text {interaction }}=0.51\right)$. Similarly, there was no significant effect between the antiplatelet strategies on the secondary endpoint of BARC type 3 or 5 bleeding for either BMI group (BMI $<27 \mathrm{~kg} /$ $\mathrm{m}^{2}, 2.3 \%$ vs. $2.4 \%$, HR $0.94,95 \%$ CI $0.69-1.28, p=0.70$, BMI $\geq 27 \mathrm{~kg} / \mathrm{m}^{2}, 1.9 \%$ vs. $1.9 \%$, HR $0.99,95 \%$ CI $0.73-1.34$, $\left.p=0.96, p_{\text {interaction }}=0.81\right)$. There was no beneficial treatment 
Table 1 Comparison of clinical and angiographic characteristics between patients with $\mathrm{BMI}<27 \mathrm{~kg} / \mathrm{m}^{2}$ and $\geq 27 \mathrm{~kg} / \mathrm{m}^{2}$

\begin{tabular}{|c|c|c|c|}
\hline & $\begin{array}{l}\mathrm{BMI}<27 \mathrm{~kg} / \mathrm{m}^{2} \\
N=6973 / 15,966(43.7 \%)\end{array}$ & $\begin{array}{l}\mathrm{BMI} \geq 27 \mathrm{~kg} / \mathrm{m}^{2} \\
N=8993 / 15,996(56.3 \%)\end{array}$ & $p$ value \\
\hline Age (years) & $65.6 \pm 10.5$ & $63.7 \pm 10.1$ & $<0.001$ \\
\hline BMI $\left(\mathrm{kg} / \mathrm{m}^{2}\right)$ & $24.3 \pm 2.0$ & $31.2 \pm 3.7$ & $<0.001$ \\
\hline Female & $23.8(1663 / 6973)$ & $22.8(2051 / 8993)$ & 0.12 \\
\hline \multicolumn{4}{|l|}{ Clinical presentation } \\
\hline Chronic coronary syndromes & $51.6(3601 / 6973)$ & $54.3(4880 / 8993)$ & 0.001 \\
\hline \multicolumn{4}{|l|}{ Acute coronary syndromes } \\
\hline Unstable angina & $12.2(852 / 6973)$ & $13.0(1169 / 8993)$ & \\
\hline NSTEMI & $21.1(1473 / 6973)$ & $21.1(1900 / 8993)$ & \\
\hline STEMI & $15.0(1047 / 6973)$ & $11.6(1044 / 8993)$ & \\
\hline \multicolumn{4}{|l|}{ Comorbidities } \\
\hline Diabetes mellitus & $18.6(1293 / 6968)$ & $30.5(2745 / 8987)$ & $<0.001$ \\
\hline Insulin treated & $5.3(367 / 6956)$ & $9.6(856 / 8963)$ & $<0.001$ \\
\hline Hypertension & $67.3(4677 / 6947)$ & $78.5(7038 / 8965)$ & $<0.001$ \\
\hline Hypercholesterolemia & $65.9(4446 / 6751)$ & $72.6(6322 / 8712)$ & $<0.001$ \\
\hline Current smoker & $28.3(1973 / 6973)$ & $24.4(2195 / 8993)$ & $<0.001$ \\
\hline PVD & $7.1(488 / 6904)$ & $5.8(517 / 8916)$ & 0.001 \\
\hline COPD & $4.8(336 / 6938)$ & $5.4(485 / 8956)$ & 0.11 \\
\hline Renal impairment $^{*}$ & $12.3(856 / 6936)$ & $14.7(1315 / 8945)$ & $<0.001$ \\
\hline \multicolumn{4}{|l|}{ Medical history } \\
\hline Previous bleeding & $0.7(46 / 6966)$ & $0.6(52 / 8979)$ & 0.52 \\
\hline Previous stroke & $2.4(167 / 6960)$ & $2.8(254 / 8983)$ & 0.09 \\
\hline Previous MI & $22.0(1530 / 6952)$ & $24.3(2180 / 8968)$ & 0.001 \\
\hline Previous PCI & $30.9(2152 / 6968)$ & $34.2(3069 / 8984)$ & $<0.001$ \\
\hline Previous CABG & $5.8(406 / 6967)$ & $6.0(537 / 8986)$ & 0.69 \\
\hline \multicolumn{4}{|l|}{ Procedure } \\
\hline Radial access & $73.4(5089 / 6931)$ & $74.5(6670 / 8950)$ & 0.12 \\
\hline Number of lesions treated & & & 0.36 \\
\hline One lesion & $68.0(4698 / 6913)$ & $68.2(6094 / 8930)$ & \\
\hline Two lesions & $22.8(1575 / 6913)$ & $23.1(2066 / 8930)$ & \\
\hline Three or more & $9.3(640 / 6913)$ & $8.6(770 / 8930)$ & \\
\hline Average number & $1.4 \pm 0.8$ & $1.4 \pm 0.7$ & 0.18 \\
\hline Left main PCI & $2.9(198 / 6913)$ & $2.6(231 / 8930)$ & 0.29 \\
\hline RCA PCI & $37.7(2607 / 6913)$ & $37.5(3347 / 8930)$ & 0.77 \\
\hline LAD PCI & $51.7(3575 / 6913)$ & $50.1(4476 / 8930)$ & 0.047 \\
\hline LCX PCI & $30.7(2125 / 6913)$ & $32.3(2884 / 8930)$ & 0.037 \\
\hline Bypass graft PCI & $1.4(94 / 6913)$ & $1.4(124 / 8930)$ & 0.88 \\
\hline Multivessel PCI & $22.9(1583 / 6913)$ & $22.3(1991 / 8930)$ & 0.37 \\
\hline
\end{tabular}

Data are presented as mean \pm standard deviation or percentage (number)

*Based on creatinine-estimated GFR (eGFR) clearance of $<60 \mathrm{ml} / \mathrm{min} / 1.73 \mathrm{~m}^{2}$, using the Modification of Diet in Renal Disease (MDRD) formula.

$B M I$ body mass index, $P V D$ peripheral vascular disease, $C O P D$ chronic obstructive pulmonary disease, $M I$ myocardial infarction, STEMI ST-elevation myocardial infarction, NSTEMI Non-STEMI, PCI percutaneous coronary intervention, $C A B G$ coronary artery bypass graft; RCA: right coronary artery, $L A D$ left anterior descending artery, $L C X$ left circumflex artery effect related to the experimental strategy with ticagrelor monotherapy with regard to other clinical outcomes at 2 years in each BMI group (Fig. 3).

\section{Comparison of clinical outcomes between the two antiplatelet strategies in each BMI group stratified according to their clinical presentation}

Clinical outcomes stratified according to clinical 
Table 2 Clinical outcomes with unadjusted and adjusted hazard ratios between patients with $\mathrm{BMI}<27 \mathrm{~kg} / \mathrm{m}^{2}$ and $\geq 27 \mathrm{~kg} / \mathrm{m}^{2}$

\begin{tabular}{|c|c|c|c|c|c|c|}
\hline \multirow[t]{2}{*}{ Outcomes at 2 years } & \multirow{2}{*}{$\begin{array}{l}\text { BMI }<27 \mathrm{~kg} / \mathrm{m}^{2} \\
\text { No. }(\%)\end{array}$} & \multirow{2}{*}{$\begin{array}{l}\mathrm{BMI} \geq 27 \mathrm{~kg} / \mathrm{m}^{2} \\
\text { No. }(\%)\end{array}$} & \multirow{2}{*}{$\begin{array}{l}\text { Unadjusted } \\
\mathrm{HR} ; \mathrm{BMI}<27 / \\
\mathrm{BMI} \geq 27 \\
(95 \% \mathrm{CI})\end{array}$} & \multirow[b]{2}{*}{$p$ value } & \multirow{2}{*}{$\begin{array}{l}\text { Adjusted HR; } \\
\mathrm{BMI}<27 / \mathrm{BMI} \geq 27 \\
(95 \% \mathrm{CI})\end{array}$} & \multirow[b]{2}{*}{$P$ value } \\
\hline & & & & & & \\
\hline All-cause death or new Q-wave MI & $310(4.4)$ & $343(3.8)$ & $1.17(1.00-1.37)$ & 0.044 & $1.14(0.97-1.34)$ & 0.12 \\
\hline All-cause death & $236(3.4)$ & $241(2.7)$ & $1.27(1.06-1.52)$ & 0.009 & $1.24(1.02-1.49)$ & 0.029 \\
\hline New Q wave MI & $80(1.1)$ & $106(1.2)$ & $0.98(0.73-1.31)$ & 0.88 & $0.94(0.69-1.28)$ & 0.70 \\
\hline All-cause death, stroke, or new Q-wave MI & $366(5.2)$ & $412(4.6)$ & $1.15(1.00-1.32)$ & 0.051 & $1.13(0.98-1.32)$ & 0.10 \\
\hline BARC 3 or 5 bleeding & $164(2.4)$ & $168(1.9)$ & $1.27(1.02-1.57)$ & 0.030 & $1.10(0.88-1.37)$ & 0.42 \\
\hline BARC 5 bleeding & $20(0.3)$ & $26(0.3)$ & $1.00(0.56-1.79)$ & 0.99 & $0.74(0.40-1.37)$ & 0.34 \\
\hline BARC 3 bleeding & $153(2.2)$ & $156(1.7)$ & $1.27(1.02-1.59)$ & 0.033 & $1.12(0.89-1.41)$ & 0.34 \\
\hline BARC 2 bleeding & $338(4.8)$ & $447(5.0)$ & $0.98(0.85-1.13)$ & 0.79 & $0.92(0.79-1.06)$ & 0.24 \\
\hline Definite stent thrombosis & $52(0.7)$ & $76(0.8)$ & $0.89(0.62-1.26)$ & 0.50 & $0.91(0.63-1.31)$ & 0.61 \\
\hline
\end{tabular}

Data are presented as number (\%). Unadjusted and adjusted hazard ratios (95\% confidential interval) are derived from univariate and multivariate Cox regression model, respectively. Adjusted covariates for bleeding events (BARC type 3 or 5 bleeding, those components, and BARC type 2 bleeding) are age (years), sex, clinical presentation (CCS or ACS), diabetes mellitus, previous bleeding, renal impairment, anemia according to WHO classification, and radial access in the index procedure. Adjusted covariates for other outcomes are age (years), sex, clinical presentation (CCS or ACS), diabetes mellitus, hypertension, hypercholesteremia, PVD, COPD, renal impairment, previous MI, previous PCI, and previous $\mathrm{CABG}$

BARC Bleeding Academic Research Consortium; WHO World Health Organization; Other abbreviations as in Table 1

presentation (ACS or CCS) and BMI $\left(<27\right.$ or $\left.\geq 27 \mathrm{~kg} / \mathrm{m}^{2}\right)$ are shown in Table 3.

\section{Impact of BMI on antiplatelet strategy in the setting of ACS}

In the patients with ACS and a BMI $<27 \mathrm{~kg} / \mathrm{m}^{2}$, the experimental antiplatelet strategy resulted in a significantly lower rate of the primary endpoint of all-cause mortality or new Q-wave MI compared to the reference arm $(5.8 \%$ vs. $4.1 \%$, HR0.69, 95\% CI0.51-0.94, $p=0.019)$ with a significant treatment effect $\left(p_{\text {interaction }}=0.047\right.$, Table 3$)$, which was not seen in those with a BMI $\geq 27 \mathrm{~kg} / \mathrm{m}^{2}(3.8 \%$ vs. $3.5 \%$, HR $1.09,95 \%$ CI $0.79-1.50, p=0.60)$. The secondary safety bleeding endpoint (BARC type 3 or 5 bleeding) was numerically lower in patients with ACS and a BMI $<27 \mathrm{~kg} / \mathrm{m}^{2}$ receiving the experimental regime; however, there was no significant treatment effect ( $2.1 \%$ vs. $3.0 \%$, HR $0.69,95 \%$ CI $\left.0.45-1.06, p=0.09, p_{\text {interaction }}=0.75\right)($ Table 3$)$. In patients with ACS and a BMI $\geq 27 \mathrm{~kg} / \mathrm{m}^{2}$, there was no significant difference in the incidence of the secondary safety bleeding endpoint between the treatment arms (1.8\% vs. $2.4 \%$, HR $0.76,95 \%$ CI $\left.0.50-1.17, p=0.21, p_{\text {interaction }}=0.75\right)$, whereas BARC 3 bleeding was significantly lower in the experimental arm than in the reference arm $(1.5 \%$ vs. $2.4 \%$, HR 0.62 , $95 \%$ CI $0.39-0.97, p=0.038$ ), yet without $p$ value for interaction $\left(p_{\text {interaction }}=0.59\right)$.

In patients with $\mathrm{BMI}<27 \mathrm{~kg} / \mathrm{m}^{2}$ and $\mathrm{ACS}$, the observed lower rates of events with the experimental treatment were mainly driven by the lower incidence of all-cause mortality,
BARC 3 or 5 bleeding, or BARC 2 bleeding during the first year after index PCI; a landmark analysis after 1 year did not show any treatment effect in the second year (Fig. 4 and Suppl. Fig. 1).

\section{Impact of BMI on antiplatelet strategy in the setting of CCS}

In the setting of CCS, there was no difference between the reference and the experimental arm regardless of BMI group in terms of the primary endpoint $(\mathrm{BMI}<27 \mathrm{~kg}$ / $\mathrm{m}^{2} ; 4.0 \%$ vs. $4.0 \%$, HR $0.99,95 \%$ CI $0.72-1.38, p=0.98$; BMI $\geq 27 \mathrm{~kg} / \mathrm{m}^{2} ; 3.5 \%$ vs. $4.4 \%$, HR $0.79,95 \% \mathrm{CI}$ $\left.0.60-1.06, p=0.11, p_{\text {interaction }}=0.31\right)$ nor the secondary endpoint (BMI $<27 \mathrm{~kg} / \mathrm{m}^{2} ; 2.4 \%$ vs. $1.8 \%$, HR $1.33,95 \%$ CI $0.85-2.09, p=0.21 ; \mathrm{BMI} \geq 27 \mathrm{~kg} / \mathrm{m}^{2} ; 1.9 \%$ vs. $1.5 \%$, HR $1.31,95 \%$ CI $0.84-2.02, p=0.23, p_{\text {interaction }}=0.95$ ) (Table 3).

\section{Discussion}

In the context of a neutral trial, all presented findings should be viewed strictly as hypothesis generating. Nevertheless, for the first time to our knowledge, we have observed a differential effect of ticagrelor monotherapy, when compared with ticagrelor and aspirin, in relation to baseline BMI in patients with ACS - a subgroup who between 31 and 365 days after randomization were assigned to receive either ticagrelor 


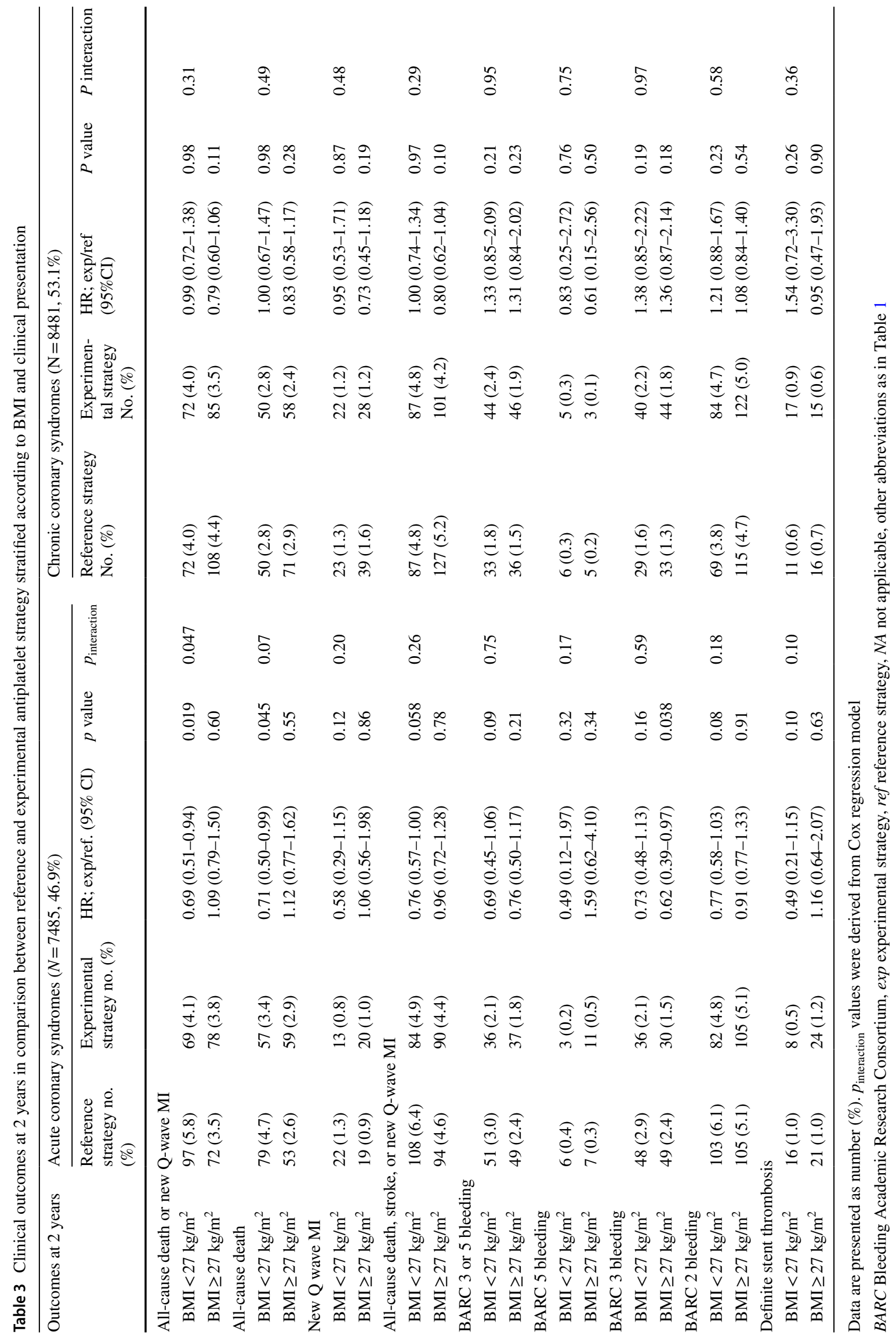




\begin{tabular}{|c|c|c|c|c|c|c|c|}
\hline Outcomes at 2 years & $\begin{array}{c}\text { Experimental } \\
\text { strategy } \\
\text { No. (\%) }\end{array}$ & $\begin{array}{c}\text { Reference } \\
\text { strategy } \\
\text { No. (\%) } \\
\end{array}$ & $\begin{array}{l}\text { HR; exp/ref } \\
(95 \% \mathrm{Cl})\end{array}$ & $P$ value & $\begin{array}{c}\text { Experimental strategy } \\
\text { better }\end{array}$ & $\begin{array}{c}\text { Reference strategy } \\
\text { better }\end{array}$ & $\begin{array}{c}\mathrm{P} \text { for } \\
\text { interaction }\end{array}$ \\
\hline All-cause death or new Q-wave MI & & & & & & & 0.51 \\
\hline BMI $<27$ & $141(4.03)$ & $169(4.87)$ & $0.82(0.66-1.03)$ & 0.09 & & & \\
\hline $\mathrm{BMI} \geq 27$ & $163(3.64)$ & $180(3.99)$ & $0.91(0.74-1.13)$ & 0.39 & & & \\
\hline All-cause death & & & & & & & 0.41 \\
\hline BMI $<27$ & $107(3.06)$ & $129(3.72)$ & $0.82(0.63-1.06)$ & 0.13 & & & \\
\hline $\mathrm{BMI} \geq 27$ & $117(2.61)$ & $124(2.75)$ & $0.95(0.74-1.23)$ & 0.70 & & & \\
\hline New Q wave MI & & & & & & & 0.78 \\
\hline $\mathrm{BMI}<27$ & $35(1.00)$ & $45(1.30)$ & $0.77(0.49-1.19)$ & 0.24 & & & \\
\hline $\mathrm{BMI} \geq 27$ & $48(1.07)$ & $58(1.28)$ & $0.83(0.57-1.22)$ & 0.35 & & & \\
\hline All-cause death, stroke, or new Q-wave MI & & & & & & & 0.97 \\
\hline BMI $<27$ & $171(4.9)$ & $195(5.6)$ & $0.86(0.70-1.06)$ & 0.16 & & & \\
\hline BMI $\geq 27$ & $191(4.3)$ & $221(4.9)$ & $0.87(0.72-1.06)$ & 0.16 & & & \\
\hline BARC 3 or 5 bleeding & & & & & & & 0.81 \\
\hline BMI $<27$ & $80(2.28)$ & $84(2.42)$ & $0.50(0.19-1.34)$ & 0.70 & & & \\
\hline $\mathrm{BMI} \geq 27$ & $83(1.85)$ & $85(1.88)$ & $1.59(0.62-4.10)$ & 0.96 & & & \\
\hline BARC 5 bleeding & & & & & & & 0.33 \\
\hline $\mathrm{BMI}<27$ & $8(0.23)$ & $12(0.35)$ & $0.66(0.27-1.62)$ & 0.36 & & & \\
\hline $\mathrm{BMI} \geq 27$ & $14(0.31)$ & $12(0.27)$ & $1.19(0.55-2.56)$ & 0.67 & & - & \\
\hline BARC 3 bleeding & & & & & & & 0.79 \\
\hline BMI $<27$ & $76(2.17)$ & $77(2.22)$ & $0.98(0.71-1.34)$ & 0.88 & & & \\
\hline $\mathrm{BMI} \geq 27$ & $74(1.65)$ & $82(1.82)$ & $0.92(0.67-1.26)$ & 0.59 & & & \\
\hline BARC 2 bleeding & & & & & & & 0.49 \\
\hline BMI $<27$ & $166(4.7)$ & $172(5.0)$ & $0.95(0.77-1.18)$ & 0.64 & & & \\
\hline $\mathrm{BMI} \geq 27$ & $227(5.1)$ & $220(4.9)$ & $1.05(0.87-1.27)$ & 0.60 & & & \\
\hline Definite stent thrombosis & & & & & & & 0.67 \\
\hline BMI $<27$ & $25(0.71)$ & $27(0.78)$ & $0.92(0.53-1.58)$ & 0.75 & & & \\
\hline $\mathrm{BMI} \geq 27$ & $39(0.87)$ & $37(0.82)$ & $1.07(0.68-1.68)$ & 0.77 & & & \\
\hline
\end{tabular}

Fig. 3 Clinical outcomes at 2-year and forest plots in comparison of patients stratified according to BMI with threshold of $27 \mathrm{~kg} / \mathrm{m}^{2}$. The squares indicate estimated hazard ratio, and the horizontal lines indicate $95 \%$ CI. There was no statistically significant difference in any

alone, or in combination with aspirin by the GLOBAL LEADERS trial protocol [14].

In the present study, the potential beneficial effect of the experimental strategy was only observed in patients with ACS who had a BMI $<27 \mathrm{~kg} / \mathrm{m}^{2}$, and was not seen in those with higher BMIs. Platelet hyper-reactivity and activation plays a central role in the progression of atherothrombosis and is the result of interactions of many adaptive responses to obesity: insulin resistance, inflammation, oxidative stress, and endothelial dysfunction [2, 26].

Although a plausible pharmacodynamic explanation still needs to be determined, it can be explained by some hypothesis. Patients with high BMI and ACS are more likely to have a prothrombotic state, partly linked to dysglycemia and proinflammatory effects of metabolic syndrome. In the PLATO study, the beneficial effect of potent antiplatelet regimen with ticagrelor was mainly observed when the patient's body weight was higher than the median value for their sex $\left(p_{\text {interaction }}=0.04\right)$ [27] In addition, the substudy of clinical outcomes between experimental strategy and reference strategy in each BMI group (BMI $<27 \mathrm{~kg} / \mathrm{m}^{2}$ or $\geq 27 \mathrm{~kg} / \mathrm{m}^{2}$ ). $p_{\text {interaction }}$ values were derived from Cox regression model. Abbreviations as in Fig. 2

the PLATO trial showed that impaired fibrinolysis was an independent predictor of cardiovascular death and was more common in patients with diabetes mellitus and/or higher BMI [28]. In those situations, strong agonist stimulation such as via platelet thrombin receptors as well as via collagen-mediated thromboxane $\mathrm{A} 2$ release could overwhelm the effects of potent platelet P2Y12 inhibition.

Furthermore, among obese patients, cyclo-oxygenase (COX) inhibition, which is achieved exclusively by aspirin, may play a more vital role than in non-obese patients. It has been demonstrated that excess adipose tissue is associated with an increased platelet turnover, leading to unacetylated COX-1 and COX-2 in newly formed platelets with subsequent excessive thromboxane formation $[29,30]$. This is further exacerbated by extra-platelet sources of thromboxane in obese patients driven by inflammatory triggers and enhanced lipid peroxidation, resulting in activation of platelets by a mechanism bypassing COX-1 acetylation or through limiting COX-isozyme acetylation by aspirin [29, 30]. Consequently, 


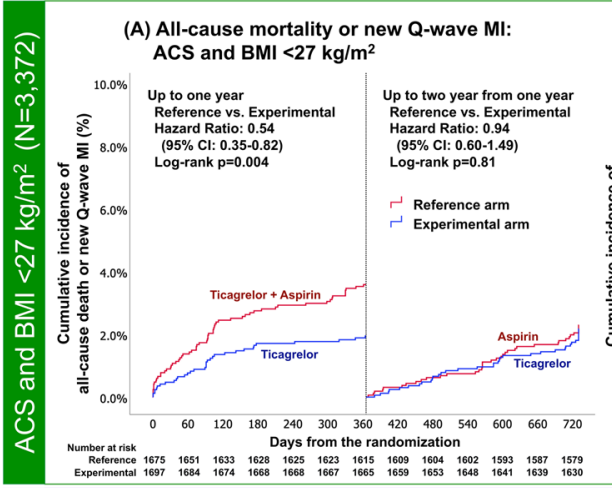

(B) All-cause mortality: ACS and BMI $<27 \mathrm{~kg} / \mathrm{m}^{2}$

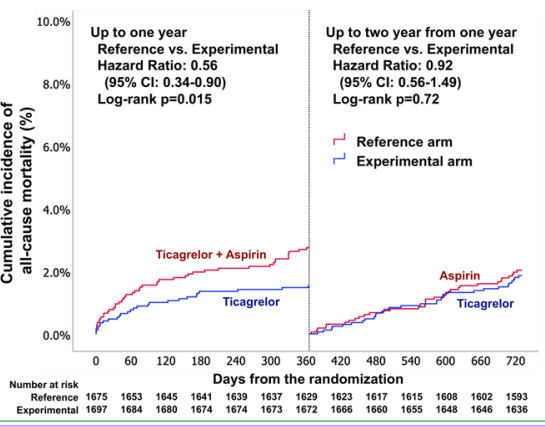

(D) All-cause mortality or new Q-wave MI: ACS and $\mathrm{BMI} \geq 27 \mathrm{~kg} / \mathrm{m}^{2}$

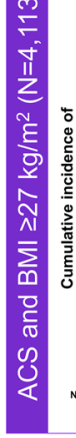

(E) All-cause mortality: ACS and BMI $\geq 27 \mathrm{~kg} / \mathrm{m}^{2}$

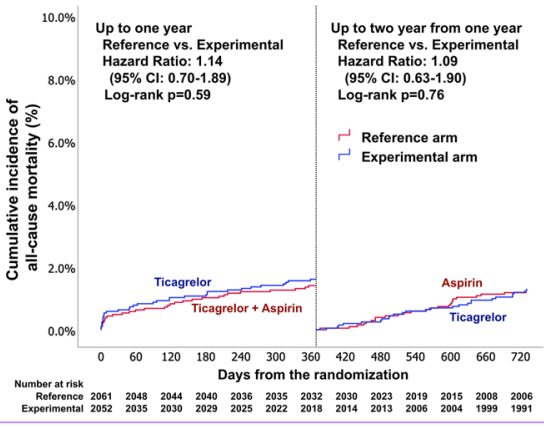

(C) BARC type 3 or 5 bleeding: ACS and BMI $<27 \mathrm{~kg} / \mathrm{m}^{2}$

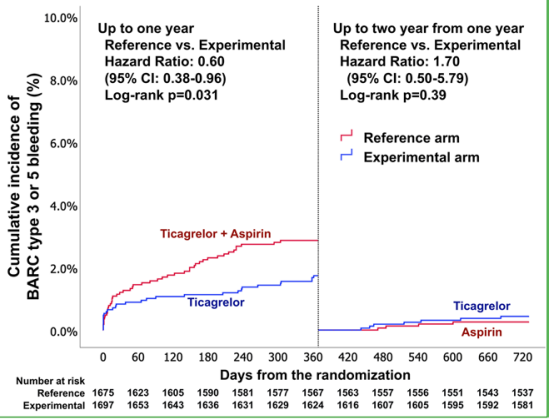

(F) BARC type 3 or 5 bleeding: ACS and BMI $\geq 27 \mathrm{~kg} / \mathrm{m}^{2}$

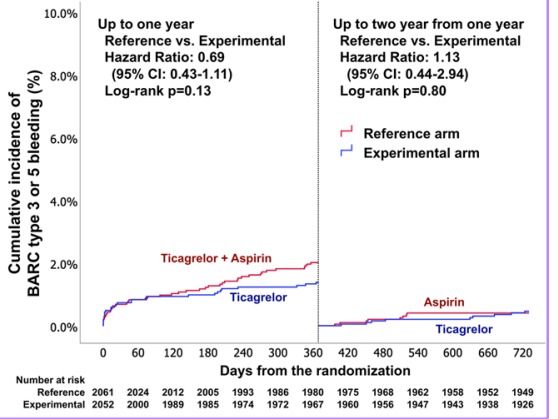

Fig. 4 The 1-year landmark analysis and Kaplan-Meier curves in patients with ACS and either $\mathrm{BMI}<27 \mathrm{~kg} / \mathrm{m}^{2}$ or $\mathrm{BMI} \geq 27 \mathrm{~kg} / \mathrm{m}^{2}$. The 1-year landmark analyses of primary endpoint (all-cause mortality or new Q-wave MI), all-cause mortality, and secondary safety endpoint (BARC type 3, or 5 bleeding) have demonstrated that the reduced risks of adverse events in experimental arm compared to ref-

ticagrelor monotherapy may provide insufficient antithrombotic effect compared to ticagrelor plus aspirin in obese patients with prothrombotic states [31, 32]. In other words, it is possible that the balance of inhibition of platelet thromboxane $\mathrm{A}_{2}\left(\mathrm{TXA}_{2}\right)$ release vs inhibition of prostacyclin formation with standard DAPT regimens is more favorable in obese patients than in non-obese patients [33]. More than a decade ago, and before the availability of prasugrel and ticagrelor, high BMI was associated with stent thrombosis in the all-comers LEADERS trial, leading to calls for the dose of clopidogrel to be weight adjusted [34].

On the other hand, in patients with ACS and a BMI $<27 \mathrm{~kg} / \mathrm{m}^{2}$, the potentially favorable results of ticagrelor monotherapy compared to DAPT during the first year require some cautious interpretation. Previously, Leadbeater, et al. and Kirkby, et al. demonstrated that sufficient inhibition of the $\mathrm{TXA}_{2}$ pathway can be achieved with the sole use of a strong $\mathrm{P}_{2} \mathrm{Y}_{12}$ inhibitor such as prasugrel or ticagrelor without aspirin [35]; however, these findings were not seen consistently [36, 37], although, this may have been due to the heterogeneity of the studied populations. Whereas the possibility of a play of chance remains, our results might suggest that in non-obese patients with higher responsiveness to erence arm were largely obtained at 1 year in patients with ACS and $\mathrm{BMI}<27 \mathrm{~kg} / \mathrm{m}^{2}$. However, in patients with ACS and BMI $\geq 27 \mathrm{~kg} /$ $\mathrm{m}^{2}$, no treatment benefits were seen in terms of primary endpoint, allcause mortality, and BARC type 3 or 5 bleeding, either in the firstyear and up to 2 years from 1 year. Abbreviations as in Fig. 2

P2 $\mathrm{Y}_{12}$ inhibitors [38, 39], sufficient inhibition of $\mathrm{TXA}_{2}$ pathway could be achieved by ticagrelor monotherapy, and adding aspirin could be associated with higher risks of ischemic and bleeding events than in obese patients [40]. In summary, the BMI-adjusted antiplatelet strategy with or without aspirin may be effective in ACS patients undergoing PCI, and the aspirin-free strategy with a potent $\mathrm{P} 2 \mathrm{Y} 12$ inhibitor could be beneficial for those with a relatively low BMI.

In patients with CCS, the experimental strategy resulted in no significant difference in any clinical outcomes, but did lead to numerically higher rates of major bleeding in patients irrespective of their BMI group. Although Orme et al. reported that lower platelet activity achieved with ticagrelor, compared with clopidogrel, also occurred in patients with CCS [41], our results might suggest that the anti-ischemic effect of potent $\mathrm{P} 2 \mathrm{Y}_{12}$ inhibitors may not be required in low ischemic-risk settings such as patients with CCS.

Finally, in our cohort, and consistent with previous studies, we observed the "obesity paradox" with the reverse J-shape association between adverse events and BMI as a continuous variable $[6,42,43]$. In addition, normal weight patients had a higher risk of all-cause mortality 
compared with overweight or obese patients according to the WHO classification (Table 2). Given the fact that most patients with a BMI $<27 \mathrm{~kg} / \mathrm{m}^{2}$ in this study could be categorized as "normal weight" in the WHO classification (Fig. 2), our results may encourage the efficacy of the novel P2Y12 inhibitor monotherapy for those high-risk "normal weight" patients.

\section{Limitations}

The present study needs to be interpreted in light of the following limitations. First, the present study consists of two prespecified subgroup analyses of a randomized controlled study with multiple testing (BMI and clinical presentation). Because in the GLOBAL LEADERS trial two different $\mathrm{P}_{2} \mathrm{Y}_{12}$ inhibitors are used in the reference group depending on the clinical presentation of ACS (ticagrelor) or CCS (clopidogrel), multiple analyses according to the clinical presentation have to be performed to evaluate specifically the treatment effect strictly. However, the results could be a play of chance and they should be considered as hypothesis generating. Second, BMI data were only available at the time of randomization. BMI can change depending on weight gain or loss during follow-up [44]. Third, in past trials reporting the "obesity paradox", the current threshold of BMI $\left(27 \mathrm{~kg} / \mathrm{m}^{2}\right)$ prespecified in the design paper and based on a recent publication [16] was not widely used and was higher than the optimal cutoff value of $25.4 \mathrm{~kg} / \mathrm{m}^{2}$ for stratifying with the risk of the primary endpoint in this study. In addition, the WHO classification is somewhat different. Indeed, the WHO classification classified patients into four or six categories, resulting in lower and uneven statistical power among these groups. Our threshold was close to the median value of $27.68 \mathrm{~kg} / \mathrm{m}^{2}$ in the current study, which allows uniform statistical power in each group. Fourth, in this trial all endpoints were site reported without a clinical adjudication committee for serious adverse events due to limited financial resources. However, the GLASSY study [45], which is a prespecified ancillary study of the GLOBAL LEADERS trial with event adjudication by an independent clinical event committee, confirmed the consistent results with those of site reported.

\section{Conclusion}

There was no overall treatment effect of experimental ticagrelor monotherapy versus standard DAPT strategy between the groups with high or low baseline BMI. However, a beneficial treatment effect on ischemic events (primary endpoints of all-cause mortality or new Q-wave MI) without trade-off in bleeding (BARC type 3 or 5 bleeding) of the experimental treatment with ticagrelor monotherapy was observed in patients presenting with ACS with $\mathrm{BMI}<27 \mathrm{~kg} / \mathrm{m}^{2}$, which was not seen in patients with $B M I \geq 27 \mathrm{~kg} / \mathrm{m}^{2}$. Our results suggest the potential benefit of a novel antiplatelet monotherapy regimen in targeting non-obese ACS patients.

Funding GLOBAL LEADERS study was sponsored by the European Clinical Research. Institute, which received funding from Biosensors International, AstraZeneca and the Medicines Company. The study funders had no role in trial design; data collection, analysis or interpretation; or writing of the report.

\section{Compliance with ethical standards}

Conflict of interest Dr. Chichareon reports research grant from Biosensors outside the submitted work. Dr. Modolo received research grant from the Sao Paulo Research Foundation (FAPESP Grant Numer 2017/22013-8) and Biosensors. Dr. Piek reports personal fees and non-financial support from Philips/Volcano, outside the submitted work. Dr. Hamm reports personal fees from AstraZeneca, outside the submitted work. Dr. Steg reports grants and personal fees from Bayer/ Janssen, grants and personal fees from Merck, grants and personal fees from Sanofi, grants and personal fees from Amarin, personal fees from Amgen, personal fees from Bristol Myers Squibb, personal fees from Boehringer-Ingelheim, personal fees from Pfizer, personal fees from Novartis, personal fees from Regeneron, personal fees from Lilly, personal fees from AstraZeneca, and grants and personal fees from Servier, outside the submitted work. Dr. Jüni reports research grants to the institution from Astra Zeneca, Biotronik, Biosensors International, Eli Lilly and The Medicines Company, and serves as unpaid member of the steering group of trials funded by Astra Zeneca, Biotronik, Biosensors, St. Jude Medical and The Medicines Company. Dr. Storey reports personal fees from Bayer, personal fees from Bristol-Myers Squibb/ Pfizer, grants and personal fees from AstraZeneca, personal fees from Novartis, personal fees from Idorsia, grants and personal fees from Thromboserin, personal fees from Haemonetics, personal fees from Amgen, grants and personal fees from Glycardial Diagnostics, personal fees from Portola, and personal fees from Medscape, outside the submitted work. Dr. Valgimigli reports personal fees from Astra Zeneca, grants and personal fees from Terumo, personal fees from Alvimedica/CID, personal fees from Abbott Vascular, personal fees from Daiichi Sankyo, personal fees from Opsens, personal fees from Bayer, personal fees from CoreFLOW, personal fees from IDORSIA PHARMACEUTICALS LTD, personal fees from Universität Basel I Dept. Klinische Forschung, personal fees from Vifor, personal fees from Bristol Myers Squib SA, and personal fees from iVascular, outside the submitted work. Dr. de Windecker received research and educational grants to the institution from Amgen, Abbott, Boston Scientific, Biotronik, Bayer, BMS, CSL Behring, Medtronic, Edwards Lifesciences, and Polares and Sinomed, outside the submitted work. Dr. Vranckx received personal fees from Astra Zeneca, personal fees from Bayer Health Care, personal fees from Daiichi Sankio, personal fees from Terumo, and personal fees from CLS Behring, outside the submitted work. Dr. Serruys reports personal fees from Biosensors, personal fees from Medtronic, personal fees from Micel Technologies, personal fees from Sinomedical Sciences Technology, personal fees from Philips/ Volcano, personal fees from Xeltis, and personal fees from HeartFlow, outside the submitted work. All other authors declare no competing interests. 
Open Access This article is licensed under a Creative Commons Attribution 4.0 International License, which permits use, sharing, adaptation, distribution and reproduction in any medium or format, as long as you give appropriate credit to the original author(s) and the source, provide a link to the Creative Commons licence, and indicate if changes were made. The images or other third party material in this article are included in the article's Creative Commons licence, unless indicated otherwise in a credit line to the material. If material is not included in the article's Creative Commons licence and your intended use is not permitted by statutory regulation or exceeds the permitted use, you will need to obtain permission directly from the copyright holder. To view a copy of this licence, visit http://creativecommons.org/licenses/by/4.0/.

\section{References}

1. Pischon T, Boeing H, Hoffmann K, Bergmann M, Schulze MB, Overvad K, van der Schouw YT, Spencer E, Moons KG, Tjonneland A, Halkjaer J, Jensen MK, Stegger J, Clavel-Chapelon F, Boutron-Ruault MC, Chajes V, Linseisen J, Kaaks R, Trichopoulou A, Trichopoulos D, Bamia C, Sieri S, Palli D, Tumino R, Vineis P, Panico S, Peeters PH, May AM, Bueno-de-Mesquita HB, van Duijnhoven FJ, Hallmans G, Weinehall L, Manjer J, Hedblad B, Lund E, Agudo A, Arriola L, Barricarte A, Navarro C, Martinez C, Quiros JR, Key T, Bingham S, Khaw KT, Boffetta P, Jenab M, Ferrari P, Riboli E (2008) General and abdominal adiposity and risk of death in Europe. N Engl J Med 359(20):21052120. https://doi.org/10.1056/NEJMoa0801891

2. Larsson SC (2019) Causal association between adiposity and cardiovascular disease. Eur Heart J 40(35):2937-2938. https://doi. org/10.1093/eurheartj/ehz639

3. Gruberg L, Weissman NJ, Waksman R, Fuchs S, Deible R, Pinnow EE, Ahmed LM, Kent KM, Pichard AD, Suddath WO, Satler LF, Lindsay J Jr (2002) The impact of obesity on the short-term and long-term outcomes after percutaneous coronary intervention: the obesity paradox? J Am Coll Cardiol 39(4):578-584

4. Gurm HS, Whitlow PL, Kip KE (2002) The impact of body mass index on short- and long-term outcomes inpatients undergoing coronary revascularization. Insights from the bypass angioplasty revascularization investigation (BARI). J Am Coll Cardiol 39(5):834-840

5. Romero-Corral A, Montori VM, Somers VK, Korinek J, Thomas RJ, Allison TG, Mookadam F, Lopez-Jimenez F (2006) Association of bodyweight with total mortality and with cardiovascular events in coronary artery disease: a systematic review of cohort studies. Lancet (Lond Engl) 368(9536):666-678. https://doi. org/10.1016/s0140-6736(06)69251-9

6. Holroyd EW, Sirker A, Kwok CS, Kontopantelis E, Ludman PF, De Belder MA, Butler R, Cotton J, Zaman A, Mamas MA (2017) The Relationship of body mass index to percutaneous coronary intervention outcomes: does the obesity paradox exist in contemporary percutaneous coronary intervention cohorts? Insights from the British Cardiovascular Intervention Society Registry. JACC Cardiovasc Interv 10(13):1283-1292. https://doi.org/10.1016/j. jcin.2017.03.013

7. Astrand M, Amilon C, Roshammar D, Himmelmann A, Angiolillo DJ, Storey RF, Gurbel PA, Bonaca MP, Hamren B (2019) Pharmacokinetic-pharmacodynamic modelling of platelet response to ticagrelor in stable coronary artery disease and prior myocardial infarction patients. Br J Clin Pharmacol 85(2):413-421. https:// doi.org/10.1111/bcp.13812

8. Rao SV, McCoy LA, Spertus JA, Krone RJ, Singh M, Fitzgerald S, Peterson ED (2013) An updated bleeding model to predict the risk of post-procedure bleeding among patients undergoing percutaneous coronary intervention: a report using an expanded bleeding definition from the National Cardiovascular Data Registry CathPCI Registry. JACC Cardiovasc Interv 6(9):897-904. https://doi.org/10.1016/j.jcin.2013.04.016

9. Bellemain-Appaix A, Montalescot G, Silvain J, Barthelemy O, Beygui F, Collet JP, Sideris G, Meuleman C, Bal-Dit-Sollier C, Lellouche N, Ducrocq G, Slama M, Milleron O, Henry P, Drouet L (2010) Slow response to clopidogrel predicts low response. J Am Coll Cardiol 55(8):815-822. https://doi.org/10.1016/j. jacc.2009.08.082

10. Cuisset T, Grosdidier C, Loundou AD, Quilici J, Loosveld M, Camoin L, Pankert M, Beguin S, Lambert M, Morange PE, Bonnet JL, Alessi MC (2013) Clinical implications of very low on-treatment platelet reactivity in patients treated with thienopyridine: the POBA study (predictor of bleedings with antiplatelet drugs). JACC Cardiovasc Interv 6(8):854-863. https://doi. org/10.1016/j.jcin.2013.04.009

11. Deharo P, Quilici J, Camoin-Jau L, Johnson TW, Bassez C, Bonnet G, Fernandez M, Ibrahim M, Suchon P, Verdier V, Fourcade L, Morange PE, Bonnet JL, Alessi MC, Cuisset T (2017) Benefit of switching dual antiplatelet therapy after acute coronary syndrome according to on-treatment platelet reactivity: the TOPIC-VASP pre-specified analysis of the TOPIC randomized study. JACC Cardiovas Interv 10(24):2560-2570. https://doi.org/10.1016/j. jcin.2017.08.044

12. Vranckx P, Valgimigli M, Juni P, Hamm C, Steg PG, Heg D, van Es GA, McFadden EP, Onuma Y, van Meijeren C, Chichareon P, Benit E, Mollmann H, Janssens L, Ferrario M, Moschovitis A, Zurakowski A, Dominici M, Van Geuns RJ, Huber K, Slagboom T, Serruys PW, Windecker S (2018) Ticagrelor plus aspirin for 1 month, followed by ticagrelor monotherapy for 23 months vs aspirin plus clopidogrel or ticagrelor for 12 months, followed by aspirin monotherapy for 12 months after implantation of a drug-eluting stent: a multicentre, open-label, randomised superiority trial. Lancet (Lond Engl) 392(10151):940-949. https://doi. org/10.1016/s0140-6736(18)31858-0

13. Serruys PW, Takahashi K, Chichareon P, Kogame N, Tomaniak M, Modolo R, Chang CC, Komiyama H, Soliman O, Wykrzykowska JJ, de Winter RJ, Ferrario M, Dominici M, Buszman P, Bolognese L, Tumscitz C, Benit E, Stoll HP, Hamm C, Steg PG, Onuma Y, Juni P, Windecker S, Vranckx P, Colombo A, Valgimigli M (2019) Impact of long-term ticagrelor monotherapy following 1-month dual antiplatelet therapy in patients who underwent complex percutaneous coronary intervention: insights from the Global Leaders trial. Eur Heart J 40(31):2595-2604. https:// doi.org/10.1093/eurheartj/ehz453

14. Tomaniak M, Chichareon P, Onuma Y, Deliargyris EN, Takahashi K, Kogame N, Modolo R, Chang CC, Rademaker-Havinga T, Storey RF, Dangas GD, Bhatt DL, Angiolillo DJ, Hamm C, Valgimigli M, Windecker S, Steg PG, Vranckx P, Serruys PW (2019) Benefit and risks of aspirin in addition to ticagrelor in acute coronary syndromes: a post hoc analysis of the randomized GLOBAL LEADERS Trial. JAMA Cardiol. https://doi.org/10.1001/jamac ardio.2019.3355

15. Takahashi K, Serruys PW, Chichareon P, Chang CC, Tomaniak M, Modolo R, Kogame N, Magro M, Chowdhary S, Eitel I, Zweiker R, Ong P, Ottesen MM, Tijssen JGP, Wykrzykowska JJ, de Winter RJ, Garg S, Stoll H-P, Hamm C, Steg PG, Onuma Y, Valgimigli M, Vranckx P, Carrie D, Windecker S (2019) Efficacy and safety of ticagrelor monotherapy in patients undergoing multivessel PCI. J Am Coll Cardiol 74(16):2015. https://doi.org/10.1016/j. jacc.2019.08.997

16. Vranckx P, Valgimigli M, Windecker S, Steg PG, Hamm C, Juni P, Garcia-Garcia HM, van Es GA, Serruys PW (2016) Longterm ticagrelor monotherapy versus standard dual antiplatelet therapy followed by aspirin monotherapy in patients undergoing 
biolimus-eluting stent implantation: rationale and design of the GLOBAL LEADERS trial. EuroIntervention 12(10):1239-1245. https://doi.org/10.4244/eijy15m11_07

17. Davies MJ, Bergenstal R, Bode B, Kushner RF, Lewin A, Skjoth TV, Andreasen AH, Jensen CB, DeFronzo RA (2015) Efficacy of liraglutide for weight loss among patients with type 2 diabetes: The SCALE Diabetes Randomized Clinical Trial. JAMA 314(7):687-699. https://doi.org/10.1001/jama.2015.9676

18. Davidson MH, Tonstad S, Oparil S, Schwiers M, Day WW, Bowden CH (2013) Changes in cardiovascular risk associated with phentermine and topiramate extended-release in participants with comorbidities and a body mass index $\% 3 \mathrm{e} /=27 \mathrm{~kg} / \mathrm{m}(2)$. Am J Cardiol 111(8):1131-1138. https://doi.org/10.1016/j.amjca rd.2012.12.038

19. Hicks KA, Mahaffey KW, Mehran R, Nissen SE, Wiviott SD, Dunn B, Solomon SD, Marler JR, Teerlink JR, Farb A, Morrow DA, Targum SL, Sila CA, Hai MTT, Jaff MR, Joffe HV, Cutlip DE, Desai AS, Lewis EF, Gibson CM, Landray MJ, Lincoff AM, White CJ, Brooks SS, Rosenfield K, Domanski MJ, Lansky AJ, McMurray JJV, Tcheng JE, Steinhubl SR, Burton P, Mauri L, O'Connor CM, Pfeffer MA, Hung HMJ, Stockbridge NL, Chaitman BR, Temple RJ, Standardized Data Collection for Cardiovascular Trials I (2018) 2017 Cardiovascular and stroke endpoint definitions for clinical trials. Circulation 137(9):961972. https://doi.org/10.1161/CIRCULATIONAHA.117.033502

20. Takahashi K, Kogame N, Tomaniak M, Chichareon P, Chang CC, Modolo R, Benit E, Liebetrau C, Janssens L, Ferrario M, Zurakowski A, van Geuns RJ, Dominici M, Huber K, Buszman P, Bolognese L, Tumscitz C, Zmudka K, Aminian A, Vrolix M, Petrov I, Wykrzykowska JJ, de Winter RJ, Hamm C, Steg PG, Onuma Y, Valgimigli M, Windecker S, Vranckx P, Garg S, Serruys PW (2019) Impact of recruitment and retention on all-cause mortality in a large all-comers randomised controlled trial: insights from the GLOBAL LEADERS trial. Clin Res Cardiol. https://doi.org/10.1007/s00392-019-01585-w

21. Chang CC, Spitzer E, Chichareon P, Takahashi K, Modolo R, Kogame N, Tomaniak M, Komiyama H, Yap S-C, Hoole SP, Gori T, Zaman A, Frey B, Ferreira RC, Bertrand OF, Koh TH, Sousa A, Moschovitis A, van Geuns R-J, Steg PG, Hamm C, Jüni P, Vranckx P, Valgimigli M, Windecker S, Serruys PW, Soliman O, Onuma Y (2019) Ascertainment of silent myocardial infarction in patients undergoing percutaneous coronary Intervention (from the GLOBAL LEADERS trial). Am J Cardiol. https://doi.org/10.1016/j.amjcard.2019.08.049

22. Mehran R, Rao SV, Bhatt DL, Gibson CM, Caixeta A, Eikelboom J, Kaul S, Wiviott SD, Menon V, Nikolsky E, Serebruany V, Valgimigli M, Vranckx P, Taggart D, Sabik JF, Cutlip DE, Krucoff MW, Ohman EM, Steg PG, White H (2011) Standardized bleeding definitions for cardiovascular clinical trials: a consensus report from the Bleeding Academic Research Consortium. Circulation 123(23):2736-2747. https://doi.org/10.1161/ circulationaha.110.009449

23. Cutlip DE, Windecker S, Mehran R, Boam A, Cohen DJ, van Es GA, Steg PG, Morel MA, Mauri L, Vranckx P, McFadden E, Lansky A, Hamon M, Krucoff MW, Serruys PW (2007) Clinical end points in coronary stent trials: a case for standardized definitions. Circulation 115(17):2344-2351. https://doi. org/10.1161/circulationaha.106.685313

24. Pocock SJ, McMurray JJV, Collier TJ (2015) Statistical controversies in reporting of clinical trials: part 2 of a 4-part series on statistics for clinical trials. J Am Coll Cardiol 66(23):26482662. https://doi.org/10.1016/j.jacc.2015.10.023

25. Levine GN, Bates ER, Bittl JA, Brindis RG, Fihn SD, Fleisher LA, Granger CB, Lange RA, Mack MJ, Mauri L, Mehran R, Mukherjee D, Newby LK, O'Gara PT, Sabatine MS, Smith PK, Smith SC Jr (2016) 2016 ACC/AHA guideline focused update on duration of dual antiplatelet therapy in patients with coronary artery disease: a report of The American College of Cardiology/American Heart Association task force on clinical practice guidelines: an update of the $2011 \mathrm{ACCF} / \mathrm{AHA} / \mathrm{SCAI}$ guideline for percutaneous coronary intervention, $2011 \mathrm{ACCF} / \mathrm{AHA}$ guideline for coronary artery bypass graft surgery, $2012 \mathrm{ACC} /$ AHA/ACP/AATS/PCNA/SCAI/STS guideline for the diagnosis and management of patients with stable ischemic heart disease, 2013 ACCF/AHA guideline for the management of ST-elevation myocardial infarction, 2014 AHA/ACC guideline for the management of patients with Non-ST-elevation acute coronary syndromes, and 2014 ACC/AHA guideline on perioperative cardiovascular evaluation and management of patients undergoing noncardiac surgery. Circulation 134(10):e123-155. https://doi. org/10.1161/cir.0000000000000404

26. Santilli F, Vazzana N, Liani R, Guagnano MT, Davi G (2012) Platelet activation in obesity and metabolic syndrome. Obesity Rev 13(1):27-42. https://doi.org/10.1111/j.1467789X.2011.00930.x

27. Wallentin L, Becker RC, Budaj A, Cannon CP, Emanuelsson H, Held C, Horrow J, Husted S, James S, Katus H, Mahaffey KW, Scirica BM, Skene A, Steg PG, Storey RF, Harrington RA, Freij A, Thorsen M (2009) Ticagrelor versus clopidogrel in patients with acute coronary syndromes. The N Engl J Med 361(11):10451057. https://doi.org/10.1056/NEJMoa0904327

28. Sumaya W, Wallentin L, James SK, Siegbahn A, Gabrysch K, Bertilsson M, Himmelmann A, Ajjan RA, Storey RF (2018) Fibrin clot properties independently predict adverse clinical outcome following acute coronary syndrome: a PLATO substudy. Eur Heart J 39(13):1078-1085. https://doi.org/10.1093/eurheartj/ehy013

29. Berg AH, Scherer PE (2005) Adipose tissue, inflammation, and cardiovascular disease. Circ Res 96(9):939-949. https://doi. org/10.1161/01.Res.0000163635.62927.34

30. Mitchell JA, Warner TD (2006) COX isoforms in the cardiovascular system: understanding the activities of non-steroidal antiinflammatory drugs. Nat Rev Drug Discovery 5(1):75-86. https ://doi.org/10.1038/nrd1929

31. Storey RF, Sanderson HM, White AE, May JA, Cameron KE, Heptinstall S (2000) The central role of the $\mathrm{P}(2 \mathrm{~T})$ receptor in amplification of human platelet activation, aggregation, secretion and procoagulant activity. Br J Haematol 110(4):925-934. https ://doi.org/10.1046/j.1365-2141.2000.02208.x

32. Sibbing D, von Beckerath O, Schomig A, Kastrati A, von Beckerath $N$ (2007) Impact of body mass index on platelet aggregation after administration of a high loading dose of $600 \mathrm{mg}$ of clopidogrel before percutaneous coronary intervention. Am J Cardiol 100(2):203-205. https://doi.org/10.1016/j.amjcard.2007.02.081

33. Thomas MR, Storey RF (2014) Impact of aspirin dosing on the effects of P2Y12 inhibition in patients with acute coronary syndromes. J Cardiovasc Transl Res 7(1):19-28. https://doi. org/10.1007/s12265-013-9524-6

34. Sarno G, Garg S, Onuma Y, Buszman P, Linke A, Ischinger T, Klauss V, Eberli F, Corti R, Wijns W, Morice MC, di Mario C, van Geuns RJ, Eerdmans P, Garcia-Garcia HM, van Es GA, Goedhart D, de Vries T, Juni P, Meier B, Windecker S, Serruys $P$ (2010) The impact of body mass index on the one year outcomes of patients treated by percutaneous coronary intervention with biolimus- and sirolimus-eluting stents (from the LEADERS Trial). Am J Cardiol 105(4):475-479. https://doi.org/10.1016/j. amjcard.2009.09.055

35. Armstrong PC, Leadbeater PD, Chan MV, Kirkby NS, Jakubowski JA, Mitchell JA, Warner TD (2011) In the presence of strong P2Y12 receptor blockade, aspirin provides little additional inhibition of platelet aggregation. J Thromb Haemost JTH 9(3):552561. https://doi.org/10.1111/j.1538-7836.2010.04160.x 
36. Scavone M, Femia EA, Caroppo V, Cattaneo M (2016) Inhibition of the platelet $\mathrm{P} 2 \mathrm{Y} 12$ receptor for adenosine diphosphate does not impair the capacity of platelet to synthesize thromboxane A2. Eur Heart J 37(44):3347-3356. https://doi.org/10.1093/eurheartj/ ehv551

37. Beigel R, Mazin I, Koifman E, Shechter M, Pres H, Shlomo N, Rosenberg N, Asher E, Matetzky S (2018) Aspirin withdrawal in patients treated with ticagrelor presenting with non-ST elevation myocardial infarction. J Thromb Haemost JTH 16(4):663-669. https://doi.org/10.1111/jth.13977

38. Angiolillo DJ (2009) Variability in responsiveness to oral antiplatelet therapy. Am J Cardiol 103(3 Suppl):27a-34a. https://doi. org/10.1016/j.amjcard.2008.11.020

39. Beavers CJ, Heron P, Smyth SS, Bain JA, Macaulay TE (2015) Obesity and antiplatelets-does one size fit all? Thromb Res 136(4):712-716. https://doi.org/10.1016/j.thromres.2015.07.015

40. Warner TD, Armstrong PC, Curzen NP, Mitchell JA (2010) Dual antiplatelet therapy in cardiovascular disease: does aspirin increase clinical risk in the presence of potent $\mathrm{P} 2 \mathrm{Y} 12$ receptor antagonists? Heart (Br Cardiac Soc) 96(21):1693-1694. https:// doi.org/10.1136/hrt.2010.205724

41. Orme RC, Parker WAE, Thomas MR, Judge HM, Baster K, Sumaya W, Morgan KP, McMellon HC, Richardson JD, Grech ED, Wheeldon NM, Hall IR, Iqbal J, Barmby D, Gunn JP, Storey RF (2018) Study of two dose regimens of ticagrelor compared with clopidogrel in patients undergoing percutaneous coronary intervention for stable coronary artery disease (STEEL-PCI). Circulation 138(13):1290-1300. https://doi.org/10.1161/circu lationaha.118.034790

42. Neeland IJ, Das SR, Simon DN, Diercks DB, Alexander KP, Wang TY, de Lemos JA (2017) The obesity paradox, extreme obesity, and long-term outcomes in older adults with ST-segment elevation myocardial infarction: results from the NCDR. Eur Heart J Qual Care Clin Outcomes 3(3):183-191. https://doi.org/10.1093/ehjqc co/qcx010

43. Faggioni M, Baber U, Afshar AE, Giustino G, Sartori S, Sorrentino S, Steg PG, Stefanini GG, Windecker S, Leon MB, Stone GW, Wijns W, Serruys PW, Valgimigli M, Camenzind E, Weisz G, Smits PC, Kandzari DE, Galatius S, Von Birgelen C, Jeger RV, Mikhail GW, Itchhaporia D, Mehta L, Ortega R, Kim HS, Kastrati A, Chieffo A, Dangas GD, Morice MC, Mehran R (2018) Effects of body mass index on clinical outcomes in female patients undergoing percutaneous coronary intervention with drug-eluting stents: results from a patient-level pooled analysis of randomized controlled trials. JACC Cardiovasc Interv 11(1):68-76. https:// doi.org/10.1016/j.jcin.2017.06.060

44. Stienen S, Ferreira JP, Girerd N, Duarte K, Lamiral Z, McMurray JJV, Pitt B, Dickstein K, Zannad F, Rossignol P (2019) Mean $\mathrm{BMI}$, visit-to-visit BMI variability and BMI changes during follow-up in patients with acute myocardial infarction with systolic dysfunction and/or heart failure: insights from the High-Risk Myocardial Infarction Initiative. Clin Res Cardiol 108(11):12151225. https://doi.org/10.1007/s00392-019-01453-7

45. Franzone A, McFadden E, Leonardi S, Piccolo R, Vranckx P, Serruys PW, Benit E, Liebetrau C, Janssens L, Ferrario M, Zurakowski A, Diletti R, Dominici M, Huber K, Slagboom T, Buszman P, Bolognese L, Tumscitz C, Bryniarski K, Aminian A, Vrolix M, Petrov I, Garg S, Naber C, Prokopczuk J, Hamm C, Steg PG, Heg D, Juni P, Windecker S, Valgimigli M (2019) Ticagrelor alone versus dual antiplatelet therapy from 1 month after drug-eluting coronary stenting. J Am Coll Cardiol 74(18):2223-2234. https:// doi.org/10.1016/j.jacc.2019.08.1038

\section{Affiliations}

Masafumi Ono ${ }^{1} \cdot$ Ply Chichareon $^{1,2} \cdot$ Mariusz Tomaniak $^{3,4} \cdot$ Hideyuki Kawashima $^{1} \cdot$ Kuniaki Takahashi $^{1}$. Norihiro Kogame ${ }^{1} \cdot$ Rodrigo Modolo $^{1,5} \cdot$ Hironori Hara $^{1} \cdot$ Chao Gao ${ }^{6,7} \cdot$ Rutao Wang $^{6,7} \cdot$ Simon Walsh ${ }^{8}$. Harry Suryapranata ${ }^{6}$. Pedro Canas da Silva ${ }^{9}$. James Cotton ${ }^{10}$. René Koning ${ }^{11} \cdot$ Ibrahim Akin $^{12}$. Benno J. W. M. Rensing ${ }^{13}$. Scot Garg ${ }^{14}$. Joanna J. Wykrzykowska' ${ }^{1}$ Jan J. Piek ${ }^{1}$. Peter Jüni ${ }^{15}$. Christian Hamm ${ }^{16}$. Philippe Gabriel Steg ${ }^{17} \cdot$ Marco Valgimigli $^{18}$. Stephan Windecker ${ }^{18} \cdot$ Robert F. Storey $^{19} \cdot$ Yoshinobu Onuma $^{20}$. Pascal Vranckx ${ }^{21} \cdot$ Patrick W. Serruys ${ }^{20,22}$

Patrick W. Serruys

patrick.w.j.c.serruys@gmail.com

1 Amsterdam UMC, Heart Center, Department of Clinical and Experimental Cardiology, Amsterdam Cardiovascular Sciences, University of Amsterdam, Meibergdreef 9, Amsterdam, The Netherlands

2 Division of Cardiology, Department of Internal Medicine, Faculty of Medicine, Prince of Songkla University, Songkhla, Thailand

3 Erasmus Medical Centre, Thoraxcentre, Rotterdam, the Netherlands

4 First Department of Cardiology, Medical University of Warsaw, Warsaw, Poland

5 Department of Internal Medicine, Cardiology Division, University of Campinas (UNICAMP), Campinas, Brazil

6 Department of Cardiology, Radboud University Medical Center, Nijmegen, The Netherlands
7 Depatment of Cardiology, Xijing hospital, Xi'an, China

8 Belfast Health and Social Care Trust, Cardiology, Belfast, Ireland

9 Serviço de Cardiologia, Hospital de Santa Maria, Lisbon, Portugal

10 Department of Cardiology, Heart and Lung Centre, New Cross Hospital, Wolverhampton, UK

11 Cardiology Service, Saint Hilaire Clinic, Rouen, France

12 First Department of Medicine, University Medical Centre Mannheim (UMM), Faculty of Medicine Mannheim, University of Heidelberg, Mannheim, Germany

13 Department of Cardiology, St. Antonius Hospital, Nieuwegein, The Netherlands

14 Department of Cardiology, Royal Blackburn Hospital, Blackburn, UK 
15 Applied Health Research Centre, Li Ka Shing Knowledge Institute, St Michael's Hospital, University of Toronto, Toronto, Canada

16 University of Giessen and Kerckhoff Heartand Thorax Center, University of Giessen, Bad Nauheim, Germany

17 FACT (French Alliance for Cardiovascular Trials), Université de Paris, Assistance Publique-Hôpitaux de Paris -Diderot, Paris, France

18 Department of Cardiology, University of Bern, Inselspital, Bern, Switzerland
19 Cardiovascular Research Unit, Department of Infection, Immunity and Cardiovascular Disease, University of Sheffield, Sheffield, UK

20 Department of Cardiology, NUIG (National University of Ireland, University Road, Galway)Galway H91 TK33, Ireland

21 Jessa Ziekenhuis, Faculty of Medicine and Life Sciences at the Hasselt University, Hasselt, Belgium

22 NHLI, Imperial College London, London, UK 